\title{
Routines in the community nursing services for assessing nutritional status
}

\begin{abstract}
Weight is one of the simplest measurements of nutritional status. Nevertheless, a number of personnel in the community nursing services lack knowledge about nutrition and good routines for weighing patients.
\end{abstract}

\author{
FORFATTERE \\ Heidi Aagaard \\ Førstelektor \\ Avdeling for helse- og sosialfag, $\mathrm{H} \emptyset$ gskolen i $\varnothing$ stfold \\ Vigdis Abrahamsen Grøndahl \\ Førsteamanuensis \\ Avdeling for helse- og sosialfag, $\mathrm{H} \varnothing$ gskolen i $\varnothing$ stfold
}

\section{SAMMENDRAG}

Background: Studies show that patients who receive assistance from the community nursing services may be susceptible to undernutrition. In order to map nutritional status, in $\mathbf{2 0 0 9}$ the Norwegian Directorate of Health issued national professional guidelines for the prevention and treatment of undernutrition, which stressed that all patients admitted to institutions or persons registered with the community nursing services are to be assessed for nutritional risk.

Purpose: The purpose of this study was to describe the routines that managers and health care personnel in the community nursing services follow when assessing patients' nutritional status.

Method: The study was a quantitative cross-sectional study, comprising two sub-studies: one among managers in the community nursing services and one among health care personnel. Data were collected by means of a questionnaire. A total of 273 managers (response rate 59\%) and 212 health care personnel (response rate $74 \%$ ) answered the questionnaire.

Results: $67 \%$ of the managers and $37 \%$ of the health care personnel were familiar with the Directorate of Health's national guidelines. One out of three respondents replied that the community nursing services have written procedures for assessing nutritional status. $80 \%$ of the managers and $69 \%$ of the health care personnel stated that it was not usual to weigh service users when registering them for community nursing services.

Conclusion: Written procedures should be prepared for assessing nutritional status in the municipalities. Guidelines are available, but they should be better publicised, and the training of health care personnel should be a priority area. 
In 2009, the Norwegian Directorate of Health issued national professional guidelines for the prevention and treatment of undernutrition. The guidelines stressed that all patients admitted to institutions or registered for community nursing services are to be assessed for nutritional risk (1).

The purpose of the assessment is to detect patients at nutritional risk as early as possible in order to initiate targeted measures. Around 78000 people in Norway receive help from the community nursing services. Even though figures from Statistics Norway show that the group of younger people who need assistance is increasing, a large number are over the age of $67(2)$.

\section{GROUPS AT RISK OF UNDERNUTRITION}

Elderly people who receive assistance from the community nursing services are either susceptible to undernutrition, at risk of undernutrition or are undernourished (3-9). Patients suffering from a serious or long-term illness are particularly susceptible to undernutrition (10). For example, some types of cancer can lead to metabolic alterations in the body. The patient may develop different levels of stress metabolism and cachexia resulting in weight loss etc. (10). Patients with cognitive failure who live at home are also susceptible to undernutrition (11)

The causes of undernutrition may be multifactorial. A meta-analysis from the Netherlands identified 37 factors that could affect nutritional intake in older people (12. These factors were partly associated with the person in question, the food that was served and the eating environment.

\section{DEFINITION OF UNDERNUTRITION}

Undernutrition, or PEM (protein-energy malnutrition) as it is often called, may be defined as a nutritional situation in which a lack of energy, protein and/or other nutrients causes measurable adverse effects on body composition and function, together with a clinical result (1, p. 14).

\section{«Undernutrition may affect both physical and mental function.»}

Undernutrition may affect both physical and mental function. It leads to loss of protein-rich muscle mass (13). Likewise, older people are susceptible to sarcopenia due to changes in body composition with further loss of muscle mass leading to decreased muscle strength and muscle function (14). Poor nutrition and protein deficiency in particular have proved to be one of the main underlying causes of sarcopenia (14).

Undernutrition is associated with a greater risk of falling, impaired immunity and increased mortality (15-17), and may result in longer periods of hospitalisation and increased costs (18-20). Following acute illness, the elderly patient may take longer to recover, and consequently it is better to prevent undernutrition than to treat it (21). Undernutrition may result in concentration difficulties, apathy and depression, which may affect the person's quality of life (21).

\section{HOW TO MEASURE UNDERNUTRITION}

A number of screening instruments have been developed to measure PEM. The incidence of 
undernutrition has proved to vary according to which instrument is used (22-23). In one study, elderly people aged from 65 to 96 living at home were asked to map their nutritional status using two different screening instruments: MNA-SF (Mini Nutritional Assessment Short Form) and NUFFE-NO (Nutritional Form for the Elderly) (22).

The incidence of patients in danger of becoming undernourished varied from 13.5 per cent in one form (MNA-SF) to 22.5 per cent in the other (NUFFE-NO) (22). In its national guidelines, the Norwegian Directorate of Health has recommended the screening instruments that should be used. Its recommendations are linked to whether the person is ill and has been admitted to a hospital or a nursing home, or whether the person is registered with the community nursing services. Some instruments, for example the MNA, are especially adapted to elderly people (1).

\section{INSUFFICIENT KNOWLEDGE}

In 2010, the Norwegian Board of Health Supervision carried out supervision of nutritional routines in 21 municipalities in seven counties in Norway (24). The results revealed that the current statutory requirements had been violated in two out of three municipalities. The Board's conclusion was that many municipalities paid little attention to the nutritional needs of the elderly and had insufficient knowledge about this (24).

Managers are responsible for preparing written procedures and for ensuring that the basic needs of service users are satisfied, including their nutritional needs. Health care personnel are responsible for adhering to the written procedures. There is little research on the assessment of nutritional status in the community nursing services, and we need more studies that present the views of both managers and health care personnel on nutritional routines.

The purpose of this study was to describe and compare what routines managers and health care personnel follow in order to quality assure nutrition efforts.

\section{METHOD}

The study had a descriptive, cross-sectional design, and consisted of two sub-studies: one among managers in the community nursing services and one among the health care personnel. We gathered data using a questionnaire dealing with nutrition efforts in the community nursing services.

\section{SAMPLE}

Sub-study 1: Managers in the community nursing services in all municipalities in Norway were invited to take part in the study, and to answer on behalf of their own municipality.

Sub-study 2: We asked health care personnel working in the community nursing services in 13 municipalities distributed across five health regions to participate in the survey. In each region we chose random municipalities linked to the Centre for Development of Institutional and Home Care Services. We also selected municipalities without such links. In order to calculate the number of respondents that were to participate in each municipality, we gathered information about the number of FTEs for health care personnel from the respective municipalities. Then we selected a proportional stratified random sample of health care personnel from each municipality. The aim was to control the number of respondents per municipality in order to minimise sample error.

\section{DATA COLLECTION}

We collected data using a structured questionnaire. The questions were based on the results of an earlier survey on food and meals in nursing homes (25). We adapted the questions to 
apply to the community nursing services. In addition, two nutritionists gave feedback on the questionnaire. In order to enhance its validity, we also conducted a pilot study with four respondents chosen from the same population as the sample. The responses from the pilot study are not included in the results. The pilot study did not lead to any changes in the questionnaire.

The questionnaire in sub-study 1 consisted of altogether 61 questions, and there were 67 questions in sub-study 2 . The form was structured on the basis of the following main areas: background variables (education and work experience), assessment of food and the routines for nutritional status. Several questions were formulated as questions with the response categories 'Yes', 'No' or 'Don't know', for example 'Are there written procedures for assessing nutritional status?'

The form also contained statements with which the respondents could agree or disagree, with response categories 'Disagree', 'Somewhat disagree', 'Somewhat agree' or 'Completely agree'. The following is an example of such a statement: 'The food is appetising and tasty.' Other questions were formulated about the frequency of measures with response categories such as 'Never', 'Almost never', 'Almost always', 'Always' or 'Don't know'. The following is an example: 'How often are there service users with a poor nutritional status in the community nursing services where you work?' In this article, we have focused on questions relating to the assessment of the patients' nutritional status.

\section{IMPLEMENTATION}

We conducted the study in the period from May to June 2011.

Sub-study 1: The target group for sub-study 2 was managers. TNS Gallup was responsible for sending the information letter and the questionnaire to the municipalities. The information letter and invitation were emailed to the municipalities' postal address. The questionnaires were web-based and were filled in online via a link. The municipalities that had not responded by the deadline were reminded once electronically and once by a telephone call from TNS Gallup.

Sub-study 2: The target group for sub-study 2 was health care personnel. The project manager contacted managers in the community nursing services and managers of the development centres in the municipalities selected. They were given information and were asked if health care personnel in their municipality could participate in the study. The managers appointed a contact person at the place of work. We informed the contact persons in writing that respondents should be selected at random. The contact persons then distributed the questionnaire to those who had been selected to participate in the survey. All municipalities answered by the deadline.

We distributed a total of 758 questionnaires -460 in sub-study 1 and 298 in sub-study 2 .

\section{ANALYSIS OF DATA}

We conducted the analyses using SPSS version 23. Descriptive statistics of frequency and percentage were used to describe the sample. We used the same method to describe how the samples assessed nutritional status. In order to test whether there were significant differences between the responses of managers and health care personnel, we used Pearson's Chi-Square test. The significance level was set at 0.05 .

\section{ETHICAL CONSIDERATIONS}

Sub-study 1: TNS Gallup, which had responsibility for the practical implementation of sub-study 1 , complies with current acts and regulations at all times. The questionnaire 
contained no personal information, and confidentiality and voluntary participation were safeguarded. Only TNS Gallup had access to the list of municipalities that participated in the survey and answered the questions. The list was only available in connection with reminders, and the researchers received anonymous SPSS files from TNS Gallup.

Sub-study 2: After conferring with the Norwegian Social Science Data Services, we did not submit a notification form for sub-study 2 . The reason was that the survey did not include personal information. Moreover, the questionnaire was anonymous.

\section{RESULTS}

Altogether 485 respondents answered the questionnaire on nutrition efforts in the community nursing services. A total of 273 were managers, giving a response rate of 59 , and 212 were health care personnel, equivalent to a response rate of 74 (Table 1).

Table 1: Description of sample

\begin{tabular}{lllll}
\hline & $\begin{array}{l}\text { Health care personnel } \\
(n=202)\end{array}$ & Per cent & $\begin{array}{l}\text { Managers } \\
(\mathrm{n}=272)\end{array}$ & \\
\hline & Number & & Number & Per cent \\
\hline $\begin{array}{l}\text { Education } \\
\text { Nurse }\end{array}$ & 94 & 46.5 & 265 & 97.4 \\
Social educator & 1 & 0.5 & 2 & 0.7 \\
Auxiliary nurse & 67 & 31.6 & - & - \\
Care worker & 25 & 11.8 & - & - \\
Other & 15 & 7.1 & 5 & 1.8 \\
\hline & $(n=198)$ & & Ave 272) & \\
\hline & Average/SD & Min.-max. & Average/SD & Min.-max. \\
\hline $\begin{array}{l}\text { Number of years in present } \\
\text { position (work experience) }\end{array}$ & $9.84 / 8.72$ & $0-44$ & $9.90 / 7.87$ & $0-41$ \\
\hline
\end{tabular}

Most of the managers were nurses, while approximately half of the health care personnel were nurses. Four per cent of the health care personnel had no health care training. Fifty-five per cent of the health care personnel were employed in a municipality that was linked to the Centre for Development of Institutional and Home Care Services. Sixty-seven per cent of the managers and 76 per cent of the health care personnel answered that there were always or often service users in a poor nutritional condition at their workplace.

Table 2 shows how health care personnel and managers assess patients' nutritional status, how this is documented and how they rate their knowledge of nutrition. The results show that there is a difference between how the managers and the health care personnel answer. 
Table 2: A comparison of the routines of health care personnel and managers when assessing patients' nutritional status

\begin{tabular}{|c|c|c|c|c|c|c|c|}
\hline & \multicolumn{3}{|c|}{ Health care personnel } & \multicolumn{3}{|c|}{ Managers } & \multirow[b]{2}{*}{$\mathrm{p}^{1}$} \\
\hline & $\begin{array}{l}\text { Yes } \\
\mathrm{n}(\%)\end{array}$ & $\begin{array}{c}\text { No } \\
n(\%)\end{array}$ & $\begin{array}{c}\text { Don't know } \\
n(\%)\end{array}$ & $\begin{array}{l}\text { Yes } \\
\mathrm{n}(\%)\end{array}$ & $\begin{array}{c}\text { No } \\
n(\%)\end{array}$ & $\begin{array}{l}\text { Don't know } \\
n(\%)\end{array}$ & \\
\hline \multicolumn{8}{|l|}{ Nutritional status } \\
\hline $\begin{array}{l}\text { Is it clear who has responsibility for } \\
\text { ensuring that the nutritional needs } \\
\text { of the service user are met? }\end{array}$ & $\begin{array}{c}62 \\
(30.0)\end{array}$ & $\begin{array}{c}104 \\
(50.2)\end{array}$ & $\begin{array}{c}41 \\
(19.8)\end{array}$ & $\begin{array}{c}124 \\
(45.6)\end{array}$ & $\begin{array}{c}131 \\
(48.2)\end{array}$ & $\begin{array}{c}17 \\
(6.3)\end{array}$ & 0.001 \\
\hline $\begin{array}{l}\text { Are there written procedures for } \\
\text { assessing nutritional status? }\end{array}$ & $\begin{array}{c}68 \\
(33.0)\end{array}$ & $\begin{array}{c}61 \\
(29.6)\end{array}$ & $\begin{array}{c}77 \\
(37.4)\end{array}$ & $\begin{array}{c}90 \\
(33.2)\end{array}$ & $\begin{array}{c}173 \\
(63.8)\end{array}$ & $\begin{array}{c}8 \\
(3.0)\end{array}$ & 0.001 \\
\hline $\begin{array}{l}\text { Does the home health care services have } \\
\text { routines for screening and monitoring } \\
\text { nutritional status? }\end{array}$ & $\begin{array}{c}94 \\
(45.0)\end{array}$ & $\begin{array}{c}68 \\
(32.5)\end{array}$ & $\begin{array}{c}47 \\
(22.5)\end{array}$ & $\begin{array}{c}109 \\
(40.2)\end{array}$ & $\begin{array}{c}159 \\
(58.7)\end{array}$ & $\stackrel{3}{(1.1)}$ & 0.001 \\
\hline $\begin{array}{l}\text { Is there a routine procedure for recording } \\
\text { the food intake of service users who are } \\
\text { in poor nutritional condition? }\end{array}$ & $\begin{array}{c}131 \\
(63.6)\end{array}$ & $\begin{array}{c}54 \\
(26.2)\end{array}$ & $\begin{array}{c}21 \\
(10.2)\end{array}$ & $\begin{array}{c}192 \\
(70.8)\end{array}$ & $\begin{array}{c}72 \\
(26.6)\end{array}$ & $\begin{array}{c}7 \\
(2.6)\end{array}$ & 0.002 \\
\hline $\begin{array}{l}\text { Does the municipality have portable } \\
\text { weighing scales that can be used } \\
\text { when visiting the service user? }\end{array}$ & $\begin{array}{c}74 \\
(35.6)\end{array}$ & $\begin{array}{c}114 \\
(54.8)\end{array}$ & $\begin{array}{c}20 \\
(9.6)\end{array}$ & $\begin{array}{c}119 \\
(43.8)\end{array}$ & $\begin{array}{c}149 \\
(54.8)\end{array}$ & $\begin{array}{c}4 \\
(1.5)\end{array}$ & 0.001 \\
\hline $\begin{array}{l}\text { Is there a routine procedure for weighing } \\
\text { service users on registration? }\end{array}$ & $\begin{array}{c}38 \\
(18.3)\end{array}$ & $\begin{array}{c}144 \\
(69.2)\end{array}$ & $\begin{array}{c}26 \\
(12.5)\end{array}$ & $\begin{array}{c}54 \\
(19.9)\end{array}$ & $\begin{array}{c}218 \\
(80.1)\end{array}$ & - & 0.001 \\
\hline $\begin{array}{l}\text { Is there a routine procedure for } \\
\text { calculating BMI? }\end{array}$ & $\begin{array}{c}31 \\
(15.3)\end{array}$ & $\begin{array}{c}147 \\
(72.4)\end{array}$ & $\begin{array}{c}25 \\
(12.3)\end{array}$ & $\begin{array}{c}33 \\
(12.1)\end{array}$ & $\begin{array}{c}238 \\
(87.5)\end{array}$ & $\begin{array}{c}1 \\
(0.4)\end{array}$ & 0.001 \\
\hline $\begin{array}{l}\text { Is there a routine procedure for weigh- } \\
\text { ing service users at fixed intervals? }\end{array}$ & $\begin{array}{c}102 \\
(49.3)\end{array}$ & $\begin{array}{c}89 \\
(43.0)\end{array}$ & $\begin{array}{c}16 \\
(7.7)\end{array}$ & $\begin{array}{c}101 \\
(37.1)\end{array}$ & $\begin{array}{c}167 \\
(61.4)\end{array}$ & $\begin{array}{c}4 \\
(1.5)\end{array}$ & 0.001 \\
\hline \multicolumn{8}{|l|}{ Documentation } \\
\hline $\begin{array}{l}\text { Is it standard procedure to note the service } \\
\text { user's food habits on registration? }\end{array}$ & $\begin{array}{c}63 \\
(30.1)\end{array}$ & $\begin{array}{c}113 \\
(54.1)\end{array}$ & $\begin{array}{c}33 \\
(15.8)\end{array}$ & $\begin{array}{c}111 \\
(41.0)\end{array}$ & $\begin{array}{c}155 \\
(57.2)\end{array}$ & $\begin{array}{c}5 \\
(1.8)\end{array}$ & 0.001 \\
\hline $\begin{array}{l}\text { Are food and meals included in an } \\
\text { individualised plan? }\end{array}$ & $\begin{array}{c}116 \\
(55.5)\end{array}$ & $\begin{array}{c}49 \\
(23.4)\end{array}$ & $\begin{array}{c}44 \\
(21.1)\end{array}$ & $\begin{array}{c}149 \\
(54.8)\end{array}$ & $\begin{array}{c}69 \\
(25.4)\end{array}$ & $\begin{array}{c}54 \\
(19.9)\end{array}$ & 0.87 \\
\hline $\begin{array}{l}\text { Is nutrition a key item in patient } \\
\text { documentation? }\end{array}$ & $\begin{array}{c}138 \\
(67.0)\end{array}$ & $\begin{array}{c}41 \\
(19.9)\end{array}$ & $\begin{array}{c}27 \\
(13.1)\end{array}$ & $\begin{array}{c}206 \\
(76.0)\end{array}$ & $\begin{array}{c}54 \\
(19.9)\end{array}$ & $\begin{array}{c}11 \\
(4.1)\end{array}$ & 0.001 \\
\hline $\begin{array}{l}\text { Are targets established for service users } \\
\text { in a poor nutritional condition? }\end{array}$ & $\begin{array}{c}123 \\
(59.4)\end{array}$ & $\begin{array}{c}58 \\
(28.0)\end{array}$ & $\begin{array}{c}26 \\
(12.6)\end{array}$ & $\begin{array}{c}154 \\
(56.8)\end{array}$ & $\begin{array}{c}104 \\
(38.4)\end{array}$ & $\begin{array}{c}13 \\
(4.8)\end{array}$ & 0.002 \\
\hline $\begin{array}{l}\text { Is nutrition an item in the nursing plan } \\
\text { when the patient is discharged from } \\
\text { hospital? }\end{array}$ & $\begin{array}{c}103 \\
(49.5)\end{array}$ & $\begin{array}{c}58 \\
(27.9)\end{array}$ & $\begin{array}{c}47 \\
(22.6)\end{array}$ & $\begin{array}{c}132 \\
(48.5)\end{array}$ & $\begin{array}{c}119 \\
(43.8)\end{array}$ & $\begin{array}{c}21 \\
(7.7)\end{array}$ & 0.001 \\
\hline \multicolumn{8}{|l|}{ Knowledge } \\
\hline $\begin{array}{l}\text { Are you familiar with the national pro- } \\
\text { fessional guidelines for the prevention } \\
\text { and treatment of undernutrition? }\end{array}$ & $\begin{array}{c}75 \\
(36.8)\end{array}$ & $\begin{array}{c}129 \\
(63.2)\end{array}$ & - & $\begin{array}{c}183 \\
(67.3)\end{array}$ & $\begin{array}{c}89 \\
(32.7)\end{array}$ & - & 0.001 \\
\hline $\begin{array}{l}\text { Would you like to have more knowledge } \\
\text { about nutrition efforts? }\end{array}$ & $\begin{array}{c}166 \\
(80.2)\end{array}$ & $\begin{array}{c}18 \\
(8.7)\end{array}$ & $\begin{array}{c}23 \\
(11.1)\end{array}$ & $\begin{array}{c}239 \\
(87.9)\end{array}$ & $\begin{array}{c}19 \\
(7.0)\end{array}$ & $\begin{array}{c}14 \\
(5.1)\end{array}$ & 0,035 \\
\hline
\end{tabular}

'Pearson's Chi-Square test, $\mathrm{p} \leq 0.05$

Eighty-eight per cent of the managers and 80 per cent of the health care personnel in the community nursing services wanted to improve their knowledge of nutrition efforts. The managers mainly wanted more knowledge of how to assess service users' nutritional condition and calculate their energy needs in addition to knowledge about how to give service users nutritional guidance. The health care personnel mainly wanted knowledge about the different nutrients.

In response to the question of how managers felt that the staff assessed the importance of screening and assessing service users' nutritional condition, altogether 14 per cent answered 'Very well'. Sixty-six per cent answered 'Well', while 18 per cent answered 'Badly'. Less than one per cent answered 'Very badly'. Similarly, health care personnel were asked how they thought management assessed the importance of screening and assessing service users' nutritional status. Fifteen per cent answered 'Very well', 58 per cent answered 'Well', 26 per cent answered 'Badly', and less than one per cent answered 'Very badly'.

In the case of follow-up of service users' nutritional condition, 14 per cent of the managers and 8 per cent of the health care personnel answered that this was 'Very good'. Some 75 per 
cent and 69 per cent respectively answered 'Good', and 17 per cent of the managers and 27 per cent of the health care personnel answered 'Poor'. Less than one per cent of both the managers and the health care personnel answered 'Very poor'.

The managers rated knowledge, time and then resources as the three greatest obstacles to the assessment and follow-up of nutritional status. This answer largely correlates with the health care personnel's answers, but the latter assessed time as the greatest obstacle followed by knowledge and resources.

\section{DISCUSSION}

\section{NUTRITIONAL STATUS}

This survey showed that service users in poor nutritional condition are common in the community nursing services. Other national and international surveys show that undernutrition may be a problem among users of community nursing services (3-9). Therefore, it is vital that there are good routines for assessing service users' nutritional condition.

The Norwegian Directorate of Health recommends that a standardised set of diagnostic criteria should be applied in order to identify and document undernutrition in clinical practice (1). Weight, changes in weight over time and body mass index (BMI) are highlighted as the simplest measurements of nutritional status (1).

\section{«Weighing patients is one of the most important measures to reveal and assess the person's nutritional condition.»}

In this survey, one out of five managers and one out of five health care personnel stated that it was usual to weigh the service user on registration with the community nursing services. Furthermore, 12.5 per cent of the health care personnel answered that they did not know whether it was usual to weigh the service user on registration. If it is not known whether weighing is a routine procedure, this may indicate that the service user is not weighed despite the fact that weighing is one of the most important measurements in revealing and assessing a person's nutritional condition (1).

The results are poorer than in two Swedish studies in which 31 per cent (26) and 84 per cent (7) respectively of the primary health service staff replied that all service users were weighed on registration. Surveys tend to indicate that the situation could be better at Norwegian nursing homes $(25,27)$. In order to follow weight alterations over time, the service user must be weighed at fixed intervals. Our study shows that a greater number of health care personnel weighed service users at fixed intervals compared with weighing them at the time of registration. Nevertheless, the results show that weighing the service user is still a challenge in the community nursing services of several municipalities.

In addition to weight, BMI can be used as a measurement of nutritional status. The study showed that calculating service users' BMI value was not usual either. Weight and height are the two values used to calculate BMI value. The lack of weighing routines may thus be instrumental in the failure to calculate the BMI value.

Our survey showed that just under half of the municipalities have routines for screening and evaluating the nutritional condition of users of the community nursing services. Even fewer have documented this in written procedures. The failure to use written procedures indicates that screening instruments are not used either. In a Scandinavian study on whether 
evaluating nutritional status was standard procedure in hospitals, Norway had the poorest result (28), even though several different screening instruments are available $(1,3,22)$.

\section{DOCUMENTATION}

The results of the survey showed that there is no standard procedure in all municipalities for noting service users' food habits on registration. Fewer health care personnel than managers answered this question in the affirmative. Such documentation is required by law and the health care personnel are responsible for ensuring that the data are recorded (29).

In order to implement correct nutrition-related measures, it is vital that health care personnel are aware of the individual service user's food habits. A Swedish study showed that it was usual to include questions related to nutrition in the admission interview for hospitals, separate housing for the elderly, and the community nursing services (26). A Norwegian study on community nurses' documentation showed that 70 per cent of the reports contained data associated with the nurses' subjective perceptions rather than the patient's perceptions (30).

One study showed that one out of four patients discharged from hospital in Norway was at nutritional risk (31). These patients will therefore need further nutritional treatment following discharge. Feldblum et al. (32) showed in a survey that patients who received individual nutritional treatment during and after acute hospitalisation had lower mortality and a moderate improvement in nutritional status. A Swedish survey of community nursing services showed that half of the service users need nutrition-related support (33), and that documentation is thus important. It is therefore alarming that only half of the respondents in our survey answer that nutrition is included as an item in the nursing plan they receive for patients when they are discharged from hospital.

As of 1 January 2016, the authorities require all municipalities in Norway to document service users' nutritional status in the IPLOS register (34). IPLOS is a statutory health register for municipal health and care services. Nutrition efforts and screening for nutritional status should be highlighted as a key area in nursing, both in respect of data collection during registration with the community nursing services and in further documentation going forward.

\section{KNOWLEDGE}

Both health care personnel and managers in our survey were of the opinion that more knowledge about nutrition was needed. The majority wanted to know more about this topic in connection with 'how to assess service users' nutritional condition'. The results of the survey correlate with results from Norwegian nursing homes $(25,27)$ and from an Australian study (35). These showed that there was a need for more knowledge about nutrition. Both managers and health care personnel described a lack of knowledge as the main barrier that had to be removed to enable health care personnel to assess and follow up service users' nutritional status.

\section{«Both health care personnel and managers in our survey were of the opinion that there was a need for greater knowledge of nutrition.»}

A Scandinavian study among hospital doctors and nurses showed that the lack of knowledge about nutrition was the most common cause of inadequate nutritional practice (36). In our study, a greater number of managers than health care personnel were familiar with the national professional guidelines for the prevention and treatment of undernutrition (1). 
These guidelines include information about how to screen for nutritional status. Drawing up guidelines and procedures is not sufficient. Staff must also be trained in how to apply the guidelines. Furthermore, the community nursing services must have good routines to ensure that procedures are followed.

In a qualitative survey at a Norwegian hospital, the nurses answered that they lacked adequate knowledge and skills to identify and treat undernourished elderly patients. Moreover, several of the respondents were not aware of the above-mentioned guidelines (37). The health care personnel in our survey mentioned time as being the key obstacle to achieving good routines for assessing nutrition. A qualitative survey showed that nurses in the community nursing services considered that their expertise was not being utilised correctly (38).

One out of five managers in our study answered that they believed that health care personnel did not understand the importance of screening for nutritional status while one out of four health care personnel felt that the managers did not understand the importance of assessing nutritional status. Even though most answered that the nutritional status of community nursing service users was safeguarded, it is alarming that 17 per cent of the managers and 27 per cent of the health care personnel answered that the follow-up of nutritional status was poorly safeguarded.

\section{LIMITATIONS OF THE STUDY}

We collected the data in 2011. However, the literature review indicates that there have been no major changes in routines linked to nutrition in recent years $(3-9,11)$, even though a qualitative study among community nurses showed that the patients they received from hospitals were 'sicker' than was the case prior to the introduction of the Coordination Reform (38). Nevertheless, the results must be interpreted with caution. A total of 59 per cent of the managers in the community nursing services answered the questionnaire. Although this may appear to be a low figure, it includes managers from municipalities throughout Norway. The response rate among the health care personnel included in the survey was 74 . The health care personnel were randomly selected and represented all five health regions, thus reinforcing the ability to generalise the results. However, the results must be interpreted with caution because the sample itself is limited.

\section{CONCLUSION}

This study showed that weighing service users in the community nursing services poses a challenge. Awareness of the importance of weighing is vital to ensure that the guidelines are followed. Perhaps systemising weight measurement might help. Such an initiative could be realised by putting in place standardised guidelines and procedures regarding how and when service users should be weighed. Weighing can be introduced, for example, at the same time as providing assistance for showers or baths.

Guidelines exist; more managers than health care personnel are aware of the national professional guidelines for the prevention and treatment of undernutrition. It is still important to publicise the guidelines and ensure that health care personnel are trained in applying them. It is essential that all municipalities put procedures in place to screen and assess service users' nutritional status.

\section{REFERENCES}

1. Guttormsen AB, Hensrud A, Irtun $\varnothing$, Mowé M, Sørbye LW, Thoresen L, Øien H, Alhaug $J$, Smedshaug GB. Nasjonale faglige retningslinjer for forebygging og behandling av underernæring. Helsedirektoratet, Oslo. 2009. 
2. Statistisk sentralbyrå (SSB). Pleie- og omsorgstenester, 2014, førebelse tal. Available at: http://www.ssb.no/pleie. Published: 24. June 2015. (Downloaded 15.11.2015).

3. Landmark BT, Gran SV, Grov EK. Ernæringsstatus blant pasienter i sykehjem og i hjemmesykepleien kartlagt ved hjelp av Ernæringsjournalen. Klinisk Sygepleje 2014;28(3):4-14.

4. Kjær S, Bech AM. Utvikling av redskab til ernæringsvurdering og behandling af ældre. DTU og Servicestyrelsen, Denmark. 2010.

5. Kiesswetter E, Pohlhausen S, Uhlig K, Diekmann R, Lesser S, Uter W, Heseker H, Stehle $P$, Sieber CC, Volkert D. Prognostic differences of the Mini Nutritional Assessment Short Form and Long Form in relation to 1-year functional decline and mortality in community-dwelling older adults receiving home care. J Am Geriatr Soc 2014;62:512-7.

6. Rist G, Miles G, Karimi L. The presence of malnutrition in community-living older adults receiving home nursing services. Nutr Diet 2012;69:46-50.

7. Johansson $\mathrm{Y}$, Bachrach?Lindström M, Carstensen J, Ek AC. Malnutrition in a home?living older population: prevalence, incidence and risk factors. A prospective study. J Clin Nurs 2009;18:1354-64.

8. Sørbye LW, Schroll M, Finne Soveri H, Jonsson PV, Topinkova E, Ljunggren G, Bernabei R. Unintended weight loss in the elderly living at home: the aged in Home Care Project (AdHOC). J Nutr Health Aging 2008;12:10-6.

9. Söderhamn U, Christensson L, Idvall E, Johansson AK, Bachrach?Lindström M. Factors associated with nutritional risk in 75 ?year?old community living people. Int J Older People Nurs 2012;7:3-10.

10. Rasmussen $\mathrm{HH}$, Holst $\mathrm{M}$. Definition, risikofaktorer og screening for underernæring på sygehus. In: Hessov I, Jeppesen PB (ed). Klinisk ernæring. Munksgaard Danmark, Copenhagen. 2011.

11. Rognstad MK, Brekke I, Holm E, Linberg C, Lühr N. Underernæring hos eldre hjemmeboende personer med demens. Sykepleien Forskning 2013;8:298-307. Available at: https://sykepleien.no/forskning/2013/11/underernaering-hos-eldre-hjemmeboende-personer-med-demens . (Downloaded 24.02.2017).

12. Nieuwenhuizena WF, Weenen $H$, Rigby $P$, Hetherington MM. Older adults and patients in need of nutritional support: Review of current treatment options and factors influencing nutritional intake. Clin Nutr 2010;29:160-9.

13. Borre M, Jacobsen LH, Beck AM. Hvordan vurderes patienters ernæringstilstand? I Hessov I, Jeppesen PB (red). Klinisk ernæring. Munksgaard Danmark, Copenhagen. 2011.

14. Sousa AS, Guerra RS, Fonseca I, Pichel F, Amaral TF. Sarcopenia among hospitalized patients - A cross-sectional study. Clin Nutr. 2015,34:1239-44.

15. Jensen GL. Malnutrition Forum Introduction. JPEN J Parenter Enteral nutr 2013;37:794-5.

16. Meijers JM, Halfens RJ, Neyens JC, Luiking YC, Verlaan G, Schols JM. Predicting falls in 
elderly receiving home care: the role of malnutrition and impaired mobility. J Nutr Health

Aging 2012;16:654-8.

17. Gregg EW, Gerzoff RB, Thompson TJ, Williamson DF. Intentional weight loss and death in overweight and obese U.S. adults 35 years of age and older. Ann Intern Med $2003 ; 138(5): 383$.

18. Allard JP, Keller H, Jeejeebhoy KN, Laporte M, Duerksen DR, Gramlich L, Payette H, Bernier $\mathrm{P}$, Davidson B, Teterina A, Lou W. Decline in nutritional status is associated with prolonged length of stay in hospitalized patients admitted for 7 days or more: A prospective cohort study. Clin Nutr 2015,35:144-52.

19. Freijer K, Tan SS, Koopmanscha MA, Meijers JMM, Ruud JG, Halfens M, JC Nuijten JC. The economic costs of disease related malnutrition. Clin Nutr 2013; 32:136-41.

20. Baumeister SE, Fischer B, Döring A, Koenig W, Zierer A, John J, Heier M, Meisinger C. The Geriatric Nutritional Risk Index predicts increased healthcare costs and hospitalization in a cohort of community-dwelling older adults: results from the MONICA/KORA Augsburg cohort study, 1994-2005. Nutrition 2011;27:534-42.

21. Flanagan D, Fisher T, Murray M, Visvanathan R, Charlton K, Thesing C, Quigley G, Walther K. Managing undernutrition in the elderly: Prevention is better than cure. Aust Fam Physician 2012;41:695-9.

22. Söderhamn U, Dale B, Sundsli K, Söderhamn O. Nutritional screening of older home-dwelling Norwegians: a comparison between two instruments. Clin Interv Aging 2012;7:383-91.

23. Poulia KA, Yannakoulia M, Karageorgou D, Gamaletsou M, Panagiotakos DB, Sipsas $\mathrm{NV}$, Zampelas A. Evaluation of the efficacy of six nutritional screening tools to predict malnutrition in the elderly. Clin Nutr 2012;31:378-85.

24. Helsetilsynet. Samlerapport fra tilsyn i 2010 med kommunenes sosial- og helsetjenester til eldre. Krevende oppgaver med svak styring. 2011.

25. Aagaard H. Mat og måltid i sykehjem. En nasjonal kartleggingsundersøkelse. Sykepleien Forskning 2010;5:36-43. Available at: https://sykepleien.no/forskning/2010/03/mat-og-maltider-i-sykehjem-en-nasjonal-kartleggingsundersokelse . (Downloaded 27.02.2017).

26. Alfengård K, Klevsgård R. Nutrition inom vård och omsorg. Vård i Norden 2005; 25:

$42-7$.

27. Aagaard H, Grøndahl V. Mat og måltid i sykehjem 2, Høgskolen i Østfold. Rapport 2015:1.

28. Mowé M, Bosaeus I, Rasmussen HH, Kondrup J, Unosson M, Irtun $\varnothing$. Nutritional routines and attitudes among doctors and nurses in Scandinavia: A questionnaire based survey. Clin Nutr 2006;25:524-32.

29. Lovdata. Lov om helsepersonell. 2. juli 1999; nr. 64. [Helsepersonelloven]. Available at: https://lovdata.no/dokument/NL/lov/1999-07-02-64. (Downloaded 20.01.2016). 
30. Andrés E, Bekker G. Sygeplejepersonalets oplevelse af ernæringsscreening og kostregistrering. Klinisk Sygepleje 2013;27:52-9.

31. Tangvik RJ, Tell GS, Guttormsen AB, Eisman JA, Henriksen A, Nilsen RM, Ranhoff AH. Nutritional risk profile in a university hospital population. Clin nutr 2014;34:705-11.

32. Feldblum I, German L, Castel H, Harman-Boehm I, Shahar DR. Individualized nutritional intervention during and after hospitalization: the nutrition intervention study clinical trial. J Am Geriatr Soc 2011;59:10-17.

33. Akner G, Engelheart S. Vanligt att kommunalt bistånd till äldre rör nutrition. Läkartidningen 2013;110:1987-9.

34. Alhaug J, Bjørnstad E, Ore S, Rai R, Lind J. Forprosjekt innen kvalitetsindikatorer for ernæring og legemiddelgjennomgang. Helsedirektoratet, Oslo 2015.

35. Beattie $E, O^{\prime}$ Reilly $M$, Strange $E$, Franklin S, Isenring E. How much do residential aged care staff members know about the nutritional needs of residents? Int J Older People Nurs 2014;9:54-64.

36. Mowe M, Bosaeus I, Rasmussen HH, Kondrup J, Unosson M, Rothenberg E, Irtun $\varnothing$. Insufficient nutritional knowledge among health care workers? Clin Nutr 2008;27:196-202.

37. Eide HD, Halvorsen K, Almendingen K. Barriers to nutritional care for undernourished hospitalised older people. J Clin Nurs 2014;24:696-706.

38. Norheim KH, Thoresen L. Sykepleiekompetanse i hjemmesykepleien - på rett sted til rett tid? Sykepleien Forskning 2015;10:14-22. Available at:

https://sykepleien.no/forskning/2015/02/sykepleiekompetanse-i-hjemmesykepleien-pa-rett-sted-til-rett-tid . (Downloaded 27.02.2017). 